\title{
重縮合にて生成した 6,4-ポリウレタンの後処理と熱分解性
}

(昭 和 35 年 9 月 29 日 受 理)

西出元彥・世良光孝*

\begin{abstract}
ヘキサメチレンジアミンと 1,4-ブタンジオール・ビスクロル炭酸ェステルとの重縮合で得た 6,4-ポリウレタンにはク ロル炭酸エステルのこん跡あるいは末端にクロル湠酸基を含むため, 高温に保つとそれらが分解して塩酸を放出し, 熱分 解を促進すると考えられる。したがってクロル炭酸基つ塩素を出来るだけ除去する目的で, アンモニア処理, アルコール 処理あるいはピリジン処理を行なった。その結果, 各処理ポリウレタンは塩素含有量が少なくなるとともに熱分解にる效 果が現われ熱安定性がよくなった。すなわち，アルコールで処理したものの熱分解速度が最も小さく，その値より見た熱 安定性は未処理のものに対し約 1.5 倍を示した。またアンモニア处理, ピリジン処理のいずれの場合も未処理のものより 熱安定になった。更に熱分解の活性化エネルギーを求めて $35 \mathrm{kcal} / \mathrm{mol}$ を得た。・・
\end{abstract}

\section{1 鍺言}

ヘキサメチレンジアミンと $1,4-$-ブタンジオール・ビスクロル 炭酸エステルの重縮合1)で得た 6,4-ポリウレタンの $m$-クレゾー ル溶液をみがいた銅板に塗布して烧き付けると，その表面にわず かな雲りを生じた。へキサメチレンジイソシアネートと 1,4-ブ タンジオールとの重付加によってて得たるの2)では雲りを生じない ことから, 重縮合の場合は重合物中に吸蔵された微量のビスクロ ル炭酸エステルあるいは末端のクロル炭酸基が㼬板の腐食に影響 したものと考えられる。またクロル炭酸基は高温で分解し塩酸を 放出するので，それがポリウレダンの熱分解を促進する可能性が ある。

これらの欠点を除くには残存するクロル炭酸基の塩素をできる だけ除去することが必要になる。たとえばアミンとクロル炭酸エ ステルよりウレタンを合成した場合，精製目的物中に含まれる微 量のクロル炭酸基の塩素をアンモニア処理によって除去する方法 が特許3)になっているが, ポリウレタンについても応用の可能性 があり，そのほかアルコールやピリジンに上る塩素除去の処理も 考えられる。

本報に怙いては重縮合ポリウレタンについて上述のような各処 理を行ない，熱分解性等に与える影響を検討した。その結果，重 合物中の塩素含有量が少なくなって金属面に対する腐食が認めら れなくなるとともに，熱分解にも效果が現われ，熱安定性がよく なったので，それらの結果について報告する。

\section{2 実験}

$2 \cdot 1$ 原試料

前報4)で用いた試料のうち，表 1 のものを原試料とした。

表 1 原試料とその重合条件

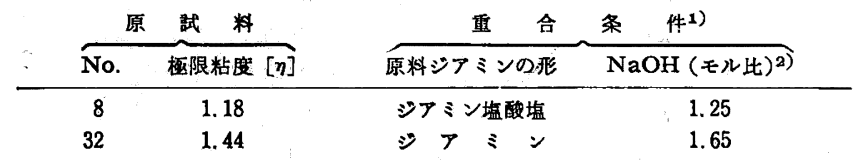

注 1) 共通条件: 各笛体 $0.1 \mathrm{~mol}$, 水 $350 \mathrm{~g}$, トルエン $230 \mathrm{~g}$, モノ゙゙ン 0.2 g, 加まぜ $700 \mathrm{rpm}$, 反応温度 $0^{\circ} \mathrm{C}$, 加湓処理 $30^{\circ} \mathrm{C}$ 。

2）脱场酸烧対するもル比。

†本報を「重縮合ポリウレタンに関する研究（第 5 報）」と する。

* 日東理化学研究所: 浦和市上木崎.

1）西出，小野寺，世良，工化 $63 ， 1464$ (1960).

2) 西出, 世良, 工化 63, 1468 (1960).

3) L.E. Bohl, U.S. P. 2, 651, 658 (1953)

4) 西出, 世良, 工化 64, 1148 (1961).

\section{$2 \cdot 2$ 後処理方法}

2.2.1 アンモニア処理 原試料に 8 倍量の $20 \%$ アンモニア水 を加え, $40^{\circ} \mathrm{C} て ゙ 30$ 分間かきまぜ後, 口別して温水で数回洗浄 し稪燥した。

2.2.2 アルコール処理 原試料に8 倍量のエタノールを加え, $70^{\circ} \mathrm{C}$ で 30 分間かきまぜ後, 口別して上と同様に洗浄, 乾燥し た。

$2 \cdot 2 \cdot 3$ ピリジン処理 原試料に 8 倍量のビリジンを加え, 以 下アルコール処理の锡會と同様に行なった。

\section{$2 \cdot 3$ 塩素分析}

試料 $20 \mathrm{mg}$ をミクロボンベ中で過酸化ソーダにより分解した 後, 内容物を承飞溶解し, チォシアン酸第二水銀法(5)によって行 なった。

\section{4 銅板焼き付け}

みがいた銅板 $\left(50 \times 100 \mathrm{~mm}^{2}\right)$ に試料ポリウレタンの $20 \% \mathrm{~m}$ クレゾール溶液を 流し塗りした後， $200^{\circ} \mathrm{C}, 10$ 分間で焼き付け た。銅板面の腐食による着色状況は肉眼で定性的に観察した。

\section{5 熱分解}

試料 $100 \mathrm{mg}$ を前報4) と同様に熱天科で分解し，分解曲線およ び分解速度を求めた。

\section{実験結果および考察}

原試料を各処理したものについて，まず含塩素量および銅板に 対する腐食状況を調べ，次いで熱分解を行なって分解曲線および 分解速度より熱安定性に対する効果を検討した。なお処理試料の 熱分解活性化エネルギーも求めた。

\section{$3 \cdot 1$ 塩素含有量}

原試料および各処理試料について塩素分析を行ない, 表 2 の結 果を得た。

表 2 重縮合ポリウレタンの後処理と塩素含有量

\begin{tabular}{|c|c|c|c|}
\hline \multirow{2}{*}{ 後 処 } & \multirow{2}{*}{ 理 } & \multicolumn{2}{|c|}{$\mathrm{Cl}$ 含 有 量 (\%) } \\
\hline & & 原試料 No. 8 & 原誁料 No. 32 \\
\hline な & L & 0.10 & 0.13 \\
\hline アンモニフ & 厂処理 & 0.03 & 0.02 \\
\hline アルニール & 2処理 & 0.01 & 0.02 \\
\hline ピע:ジ & 処理 & 0.05 & 0.02 \\
\hline
\end{tabular}

すなわちいずれの原試料についても，後処理を行なうことによ って堭素含有量は少なくなった。

また後処理ポリウレタンを銅板に齐き付げ，その表面を調べた

5）内海, 日化 73,835 (1952). 
結果，いずれの処理によるものも原試料の場合のような腐食によ る着色は認められなくなった。

\section{$3 \cdot 2$ 熱分解曲線}

各処理した試料について熱分解を行ない，原試料の場合と比較 した。原試料 No. 8 の場合について，熱分解曲線およびそれを 眓上微分して得た微分曲線を示すと図 1 になる。

すなわち後処理したものでは熱分解曲線の主分解部分の立ち上 りが原試料にくらべて高温側に移り, したがって微分曲線のピー

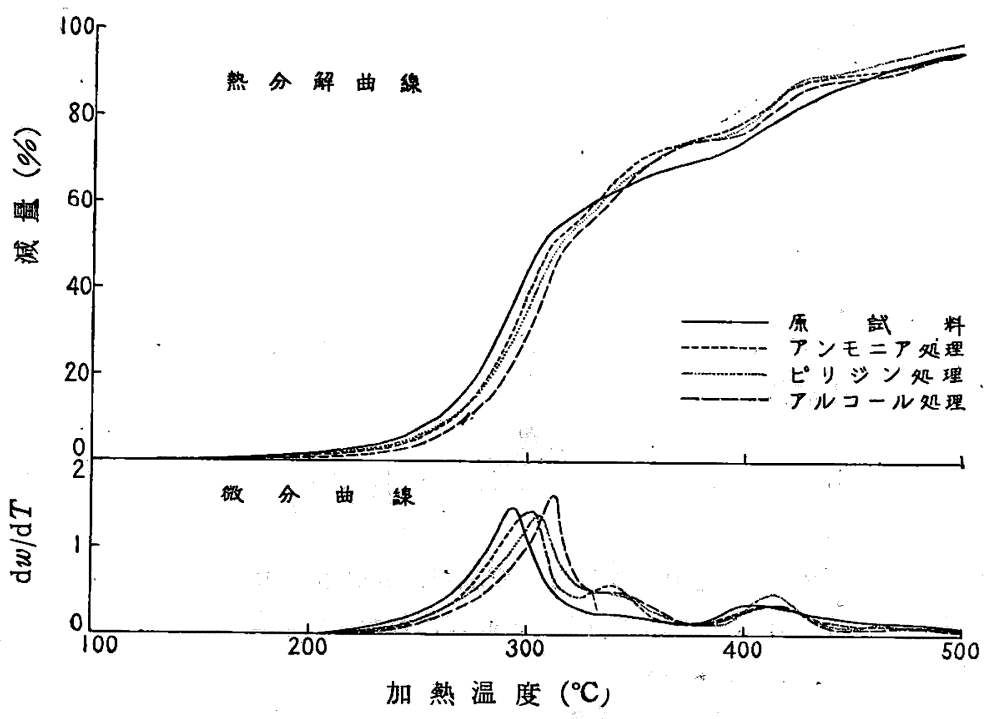

図 1 熱 分 解 曲 線

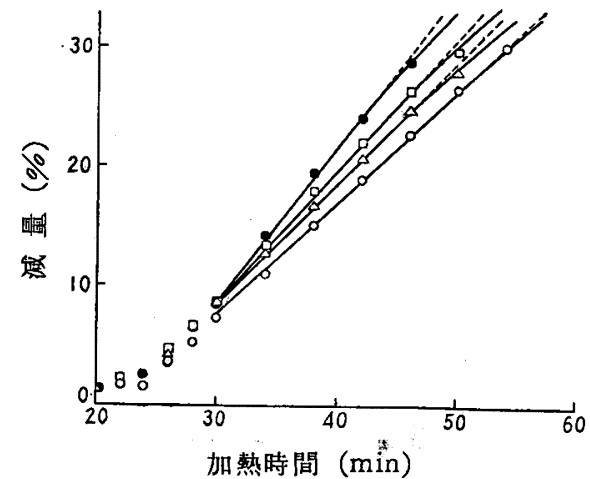

図 2 加熱減量曲線 (原試料 No. 8)

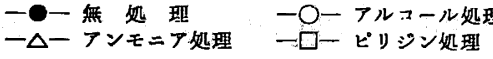

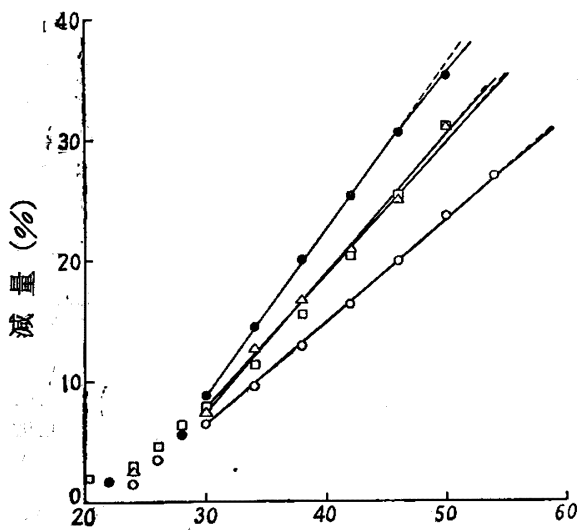

加熱時間 $(\mathrm{min})$

因 3 加熱隇而曲線（原試料 No. 32 )

ーー一 無処理
クも高温側にあって，熱安定性がよくなっていることを示してい る。

\section{$3 \cdot 3$ 熱分解速度}

後処理による熱安定性の向上を定量的に表わすため, $260^{\circ} \mathrm{C} に$ 打ける熱分解速度を求めた。加熱時間と減量との関係を示すと， 図 2 および図 3 になり，直線部分の傾斜から，熱分解速度定数 $k$ （\%/min）を求めて表 3 を得た。

すなわちいずれの原試料についても，アルコールで処理したも 表 3 後処理ポリウレタンの就分解速度定数

\begin{tabular}{|c|c|c|c|}
\hline \multirow{2}{*}{\multicolumn{2}{|c|}{ 後 处 理 }} & \multicolumn{2}{|c|}{ 笅分解逝度定数 $k(\% / \mathrm{min})$} \\
\hline & & 原試料 No. 8 & 原武料 No. 32 \\
\hline な & L & 1.36 & 1. 31 \\
\hline アンモ & ○処理 & 1.00 & 1.03 \\
\hline アルニール & ᄂ処理 & 0.97 & 0.85 \\
\hline ピリジン & （処理 & 1.08 & 1.15 \\
\hline
\end{tabular}

のの $k$ が最も小さく，この值より見た熱安定性は未処理 のものに対し約 1.5 倍になる。次いでアンモニア処理，ピ リジン処理の順でよく，いずれの場合も未処理のものより $k$ は小さくなっている。したがって後処理を行ない塩素含 有量を少なくすれば，熱安定性のよくなることがわかった。

3.4 後処理ポリウレタンの熱分解活性化エネルギー

試料として No. 8 をアルコール処理したものを使用し， $250^{\circ} \mathrm{C}, 260^{\circ} \mathrm{C}$ 打よび $270^{\circ} \mathrm{C}$ の各温度で熱分解を行なった。 その結果は図 4 で示され，各温度に批ける $k$ を求めると 表 4 になる。

表 4 各温度に扣ける熱分解速度定数

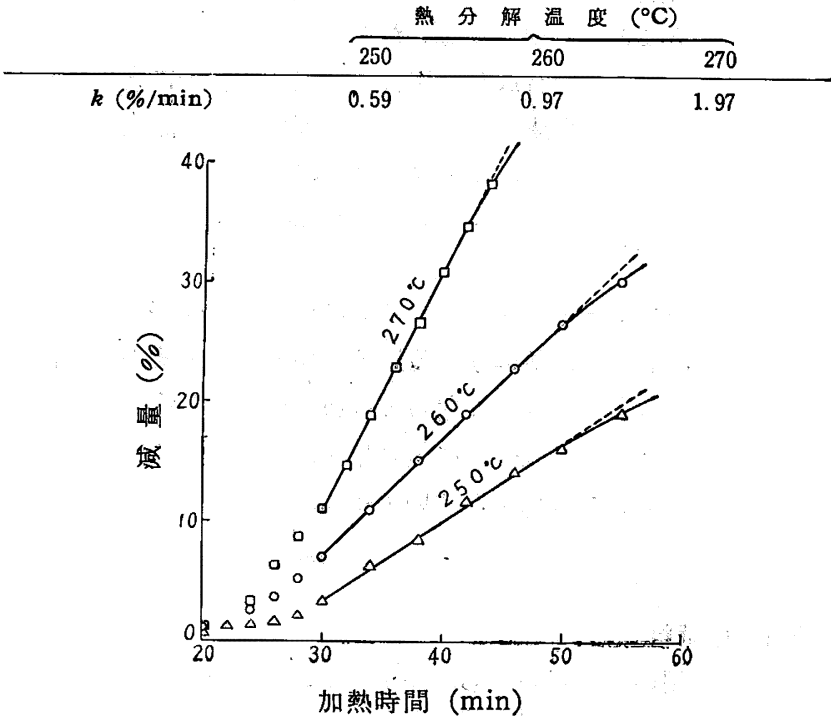

図 4 分解温度に上る影響

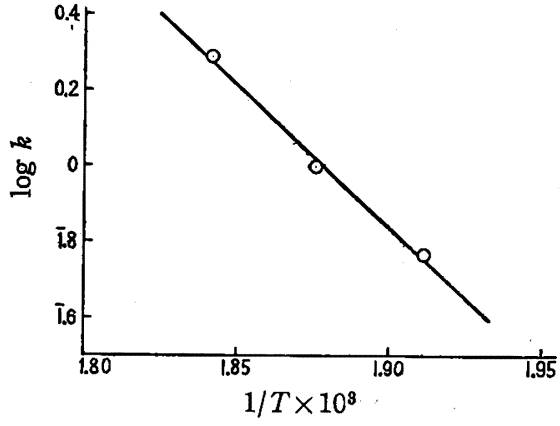

図 $51 / T$ と $\log k$ との関係 
これらの結果から， $\log k-1 / T$ （ $T$ は熱分解の絶対温度）の関係 を示すと, 図 5 のよ5に大体直線的となって Arrhenius の式が 成立し，活性化エネルギーを算出して $35 \mathrm{kcal} / \mathrm{mol}$ を得た。
終りに本研觉の発表を許可された秋葉理事長, ならびに終始御 懇篤な御指導をいただいた中土所長，加藤理事に心から感謝しま す。

一 - - -

\section{ニトロパラフィンの 合 成}

(昭 和 35 年 7 月 25 日受理)

高山秀男・米田茂夫・北野向男・福井謙一*

\section{1 緒言}

ハロゲン化アルキルと亜硝酸アルカリとの反応をジメキルホル ムアミド (DMF) またはジメチルスルホキシド (DMSO) を溶媒 として行ない, ニトロパラフィンを合成する方法1)が最近行なわ れている。

著者らはこの反応の溶媒の作用についてしらべた結果, DMSO が DMF よりも一般に求核的置換反応を速やかに完結させる溶媒 であるにもかかわらず，その強い塩基 性2)のためにいったん生成したニトロ パラフィンと亜硝酸エステルとが反応 してニトロール酸に変化し; ニトロパ ラフィンの収率が DMF を用いた場合 よりも著しく悪くなることを認めたの で，この点を改良するために DMSO 系の混合溶媒に関して研究を行なった。

DMSO 系の混合溶媒のうち DMSO-ケトン混合物は DMSO の 求核的置換反応に拈ける溶媒効果を著しく削減しないで副反応を かなり制御することが明らかにされた。とくに DMSO-メチルェ チルケトン (MEK) 等容混合物を用いた場合には反応温度 $30^{\circ} \mathrm{C}$ 以下に括いて臭化アルキルと亜硝酸ナトリウムとよりニトロパラ フィンが 40〜60\%，亜硝酸エステルが 20〜30\% の収率で党ら れることが明らかにされた。

この方法を臭化アリル，塩化ベンジルおよび $\alpha, \omega$-ジハロゲノ アルカンに適用して相当するニトロ化合物を 20 ～ $50 \%$ の収率で

† 本報を「無機塩類を用いる有機合成反応に関する研究（第 7 報)」とする。第 6 報は福井, 米田, 高山, 北野, 工化 $63,2146(1960)$.

* 京都大学工学部然料化学教室 : 京都市左京区吉田.

1) N. Kornblum, H. O. Larson, R. K. Blackwood, D. D. Mooberry, E. P. Oliveto, G. E. Graham, Chem. \& Ind. 443 (1953) ; J. Am. Chem. Soc. 78, 1497 (1956); N. Kornblum, M. E. Chalmers, R. Daniels, J. Am. Chem. Soc. 77, 6654 (1955) ; N. Kornblum, R. K. Blackwood, Organic Syntheses 37, 44(1957) ; N. Kornblum. J. W. Powers, J. Org. Chem. 22, 455 (1957); U.S.P. $2,816,909(1957)$; N. Kornblum, W. M. Weaver, J. Am. Chem. Soc. 80, 4333 (1958).

2) M. Tamres, S. Searles, Jr., J.Am. Chem. Soc. 81, 2100 (1959).
合成できることがみとめられた。なお，この方法においては亜硝 酸カリウムはニトロ基導入試薬として不適当である。

\section{2 実験}

$2 \cdot 1$ 臬化 $-n-ア ル キ ル と$ 覀硝酸ナトリウムとの反応

逆流泠却器，温度計，水銀封カキマゼ機を付した三つロフラス コに臭化一nーアルキル $0.5 \mathrm{~mol}$, 無承亜硝酸ナトリウム 50 メッ シュ粉末 $34.5 \mathrm{~g}(0.5 \mathrm{~mol})$ 㧊よび DMSO-MEK (1:1) 泥合物 表 1

\begin{tabular}{|c|c|c|c|c|c|}
\hline \multicolumn{2}{|c|}{ 两硝酸アルキル } & \multicolumn{3}{|c|}{ ニトロパラフィン } & 尌 \\
\hline$\left({ }^{\circ} \mathrm{C} / \mathrm{mmH}\right.$ 点 $)$ & $n_{\mathbb{D}^{20}}$ & 紧蟀) & 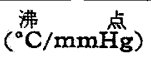 & $n_{\mathbf{D}}^{2^{0}}$ & (\%) \\
\hline $77 / 760 \mathrm{a}$ ) & 1. $3780 \mathrm{a})$ & 45 & $62 / 30$ & 1.4110 & - \\
\hline $45 / 60 \mathrm{a})$ & $1.3897 \mathrm{a})$ & 48 & $70 / 30$ & 1.4170 & - \\
\hline $45 / 30$ & 1.3985 & 51 & $80 / 12$ & 1.4240 & 75 \\
\hline $52 / 10$ & 1. 4065 & 54 & $88 / 10$ & 1.4275 & 79 \\
\hline $60 / 10$ & 1. 4130 & 57. & $98 / 10$ & 1.4320 & 83 \\
\hline
\end{tabular}

$300 \mathrm{ml}$ を入れ，かきをぜながら $30^{\circ} \mathrm{C} て ゙ 6$ 時間反応を行な $5 。$ 反応開始後約 15 分後に白色結晶性物質 (2.2 参照)の析出がみら れ暫時の後反応混合物は泥状となるがそのまま反応をつづける。 6 時間後に反応混合物を塩化ナトリウム水溶液中に投入し MEK を用いて抽出する。抽出液を無水硫酸マグネシウムで乾燥して減 圧蒸留し，粗留分を再分留した結果は表 1 のとおりである。この 蒸留において, 副生したアルコール, 脂肪酸 (ニトロール酸の分

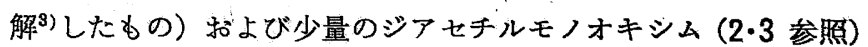
が目的物から容易に分離される。

\section{$2 \cdot 2$ 臭化ナトリウム-DMSO 系の物兵}

実験 $2 \cdot 1$ の区応初期に 析出する白色結晶性物質を吸引口別し アセトンで洗浄後室温で1夜乾燥すれば NaBr·3DMSO に相当

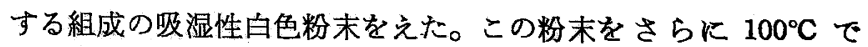
4 時間減压乾燥すれば $\mathrm{NaBr} \cdot \mathrm{DMSO}$ に,さらに $100^{\circ} \mathrm{C}$ で 10 時 間減圧乾燥すれば遂に $\mathrm{NaBr}$ に変化した。 $\mathrm{NaBr}$-DMSO 系の物 質は置換反応によって生成した $\mathrm{NaBr}$ が MEK の存在のために DMSOをともなって析出したものとみられる。なお $\mathrm{NaNO}_{2}$, $\mathrm{NaBr}$ の溶解度 $\left(25 \pm 0.5^{\circ} \mathrm{C}\right.$ に括ける 飽和溶液中の塩の wt \%)

3) V. Meyer, Ann. 175, 88 (1875) ; N. Kornblum, R. K. Blackwood. D. D. Mooberry, J. Am. Chem. Soc. 78, 1501 (1956). 